\title{
Analisis Pola Asuh Orangtua dalam Upaya Menangani Kesulitan Membaca pada Anak Disleksia
}

\author{
Ririn Aryani $^{\bowtie}{ }^{\bowtie}$, Puji Yanti Fuziah ${ }^{2}$ \\ Pendidikan Anak Usia Dini, Universitas Negeri Yogyakarta (1) \\ Pendidikan Luar Sekolah, Universitas Negeri Yogyakarta (2) \\ DOI: $10.31004 /$ obsesi.v5i2.645
}

\begin{abstract}
Abstrak
Pola asuh yang diterapkan oleh orang tua penting untuk kehidupan masa depan anak. Tujuan dalam penelitian ini adalah menganalisis bentuk pola asuh orang tua yang sesuai bagi anak disleksia dalam upaya untuk menangani kesulitan membaca. Pendekatan studi kasus dengan deskriptif kualitatif digunakan dalam penelitian ini. Sampel dalam penelitian ini adalah anakanak di kelas 1-3 dengan kesulitan membaca dan menulis permulaan. Teknik wawancara, observasi, dan dokumentasi digunakan dalam pengumpulan data pada penelitian ini. Hasil dari penelitian ini adalah disleksia dapat terjadi karena pola asuh yang diberikan oleh orangtua tidak sesuai dengan keadaan anak, sehingga seringkali anak diasuh dalam pola asuh yang keliru. Untuk itu pola asuh demokratis yang mengedepankan keterbukaan antara anak dan orang tua dapat dijadikan sebagai salah satu rekomendasi pola asuh bagi anak disleksia. Orangtua dapat menerapkannya kepada anak dengan melihat kondisi serta batasan-batasan tertentu pada masing-masing anak.
\end{abstract}

Kata Kunci: disleksia; pola asuh; kesulitan membaca.

\begin{abstract}
Parenting that is applied by parents was important for the future life of their children. This study aims to analysis the form of parenting for children with dyslexia in accordance with reading difficulties. This type of research is descriptive qualitative with a case study approach. Samples were taken from children in grades 1-3. Collecting data in this study used interview techniques, observation, and documentation. The results of this study are dyslexia can occur because the parenting provided by parents is not by following per under the circumstances of the child, so often the child eventually grows up and is raised in the wrong parenting. Thereby, authoritative parenting as respected of children and parents become a highly recommendation of parenting for dyslexia. Parents should be applide it to their children by looking at the conditions and certain limitations on each child.
\end{abstract}

Keywords: dyslexia; parenting; reading difficulties.

Copyright (c) 2020 Ririn Aryani, Puji Yanti Fuziah

$\triangle$ Corresponding author :

Email Address : ririnaryani.2019@student.uny.ac.id (Jln. Colombo No. 1, Karang Malang, Yogyakarta) Received 7 July 2020, Accepted 8 October 2020, Published 12 October 2020 


\section{PENDAHULUAN}

Pola asuh adalah cara orangtua dalam merawat, membimbing, dan mendidik anak secara konsisten. Pola asuh ini meliputi cara dan kebiasaan yang dilakukan oleh orangtua dan dirasakan langsung oleh anak, sehingga hal tersebut tentu berbeda pada setiap orangtua (Adawiah, 2017). Pola asuh inipun terjadi pada anak-anak yang memiliki kesulitan dalam belajar, seperti disleksia. Disleksia adalah kondisi ketidakmampuan anak dalam membaca, menulis dan mengeja yang paling umum dan kompleks (Munawaroh \& Anggrayni, 2007). Disleksia merupakan kondisi dimana individu yang mengalaminya memiliki IQ normal bahkan diatas normal, akan tetapi memiliki daya kemampuan membaca yang rendah. Gangguan dapat juga terjadi pada proses pengkodean huruf ataupun angka yang berdampak pada penyimpanan memori jangka pendek, persepsi visual, pendengaran, berbicara, perilaku, dan keterampilan motorik (JAMARIS EDWITA, 2014).

Data menunjukkan disleksia dapat terjadi pada 1 dari 10 anak di usia dekolah atau sekitar 10\%-15\% dari populasi (Shaywitz \& Shaywitz, 2007; Vellutino et al., 2004). Tetapi, data seperti ini dapat berbeda jumlahnya di setiap Negara, seperti di Cina misalnya sekitar 8\% anak-anak mengalami dileksia di usia sekolah, selanjutnya Malaysia dengan 7\% anak mengalami disleksia dari seluruh populasi. Di Amerika Serikat sendiri 17\%, sementara di Australia sebesar 16\% anak-anak mengalami disleksia berdasarkan penelitian National Institute of Neurogical Disorders and Stroke (Grigorenko, n.d, 2010; Reid, 2016).

Menurut Biro Pusat Statistik Indonesia (2010) (Biro Pusat Statistik (BPS), 1987) anakanak diusia 5-7 tahun berjumlah sekitar 24 juta. Usia 5 dan 7 tahun ini menjadi perhatian tersendiri karena di usia inilah anak-anak pertama kali dikenalkan dengan kemahiran membaca. Disleksia ini dikatakan sulit untuk bisa disembuhkan, tetapi dapat membaik seiring perkembangan anak. Penelitian-penelitian yang dilakukan di negara maju menunjukkan bahwa pendeteksian disleksia sejak dini diikuti dengan penanganan yang baik dan sesuai akan memberikan hasil yang baik pula (Desiningrum, 2017; Tamasse, 2017). Hal ini dapat dilakukan melalui pengasuhan yang baik dan sesuai.

Pola asuh orangtua kepada anaknya berbeda-beda. Ada yang menginginkan anakanaknya berpikir dan bertindak sesuai keinginan orang tua, namun ada pula yang memberikan kebebasan. Ada orang tua yang bersikap keras, kejam, kasar, ada yang sangat peduli dan melindungi, serta mengajak untuk berdiskusi dalam melakukan berbagai hal (Al Tridhonanto, 2014). Oleh sebab itu, pola asuh orangtua yang tepat akan sangat mempengaruhi perkembangan anak ke depannya, terlebih untuk anak-anak yang sedang berada pada tahap mengembangkan kemampuan membaca, menulis, atau mengeja. Hal ini tidak terkecuali untuk anak-anak dengan kondisi kesulitan belajar, salah satunya adalah disleksia.

Kesulitan belajar seperti disleksia membutuhkan perhatian khusus dari orangtua. Pola asuh orangtua yang konsisten dalam menjaga dan membimbing anak serta memberikan perhatian ekstra akan sangat bermanfaat untuk perkembangannya terutama dalam belajar. Untuk itu, selain mengetahui bagaimana karakteristik yang dimiliki oleh anak, orangtua memiliki peran futuristic dalam membantu memenuhi kebutuhan dasar, menstimulasi, mendukung, mengajari dan memberikan panduan kepada anak agar dapat melakukan aktivitas atau kegiatan. Disinilah kepedulian orangtua sebagai guru yang pertama dan utama bagi anak-anak, sehingga tujuannya adalah agar kelak anak mampu bertanggungjawab, mandiri, dan bersikap sesuai dengan nilai dan norma yang berlaku di masyarakat.

Disleksia sendiri diartikan sebagai kesulitan dalam mengeja, membaca, ataupun menulis. Gejala penyerta lain yang mengikuti dapat berupa kesulitan menghitung, menulis angka, dan fungsi koordinasi/keterampilan motorik. Disleksia bukanlah sebuah penyakit, tetapi merupakan sebuah gangguan pada proses belajar dalam membaca dan menulis walaupun anak-anak yang mengalami disleksia memiliki pemikiran yang normal. Ini dapat terajdi dan dapat dilihat pada saat anak mengalami kesulitan dalam mengeja, sulit membedakan huruf yang memiliki bentuk yang sama seperti huruf-huruf: $b / d, p / q, w / m$, $\mathrm{n} / \mathrm{u}$ dan juga angka (Habibi, 2015; Tamasse, 2017). Mengutip dari nasional.kompas.com 
(selasa, 02/12/2014) Riyani T Bondan (ketua Asosiasi Disleksia Indonesia periode 2010) mengungkapkan bahwa ada 10 hingga 15 persen anak menyandang disleksia di dunia, sedangkan di Indonesia sendiri diperkirakan sekitar 5 juta dari 50 juta anak sekolah mengalaminya (Pratamawati et al., 2015).

Disleksia terjadi pada individu dengan potensi kecerdasan normal, bahkan banyak diantara mereka yang mempunyai tingkat kecerdasan jauh diatas rata-rata. Itulah sebabnya, maka disleksia disebut sebagai kesulitan belajar spesifik, sebab kesulitan belajar yang dihadapinya tidak terjadi pada seluruh area melainkan hanya terjadi pada satu atau beberapa area spesifik saja, diantaranya terjadi pada area membaca, menulis dan berhitung. Selain itu, faktor-faktor yang menyebabkan anak mengalami kesulitan membaca, seperti faktor internal anak tersebut (Suryani, 2010). Contohnya minat baca yang kurang, ini dilatarbelakangi karena mereka merasa kesulitan ketika harus membaca sendiri, ini menjadi faktor penyebab kurangnya kosakata yang mereka pahami sehingga mereka lebih suka mendengarkan daripada membaca.

Untuk itu, maka tentunya dapat dipahami mengenai pola asuh dan kesulitan belajar disleksia, yaitu pola asuh orangtua merupakan kebiasaan dilakukan oleh ayah dan ibu ataupun kerabat terdekat yang diterapkan kepada anak dalam perkembangannya. Pola asuh yang orangtua berikan kepada anak merupakan bentuk penguatan motivasi bagi diri anak dan bijaknya disesuaikan dengan usia dan kemampuan anak. Terlebih untuk anak-anak yang memang membutuhkan perhatian lebih ekstra dibandingkan anak-anak pada umumnya.

Berdasarkan hal tersebut di atas dan studi pendahuluan yang dilakukan dapat terlihat adanya keterkaitan antara pola asuh orangtua terhadap kemampuan membaca anak-anak khususnya untuk anak-anak disleksia. Hal ini kemudian menjadi latar belakang dalam penelitian ini, yaitu menganalisis pola asuh yang sesuai yang dapat diterapkan oleh orangtua pada anak yang mengalami disleksia. Pola asuh yang diterapkan merupakan bentuk dari pencegahan dini yang dapat dilakukan oleh orangtua dengan kondisi anak yang sama. Selain itu juga dapat memberikan dukungan terbaik dan stimulus yang tepat sehingga anak mampu berkembang sesuai dengan tahapannya. Penelitian ini berbeda dengan penelitian sebelumnya dimana dalam penelitian ini dilakukan analisis terhadap bentuk pola asuh yang orang tua berikan kepada anaknya dan bentuk pola asuh ini dapat menjadi rujukan yang dianggap sesuai dengan kondisi anak disleksia. Selain itu, hasil penelitiannya dapat digunakan juga sebagai rujukan bagi orangtua dan guru pada tingkatan anak usia 0-8 Tahun, sehingga Sekolah Dasar kelas bawah masih dalam jangkauan usia PAUD, dengan fokus anak-anak mengalami kondisi disleksia di usia transisi belajar.

\section{METODOLOGI}

Jenis penelitian kualitatif dengan pendekatan studi kasus digunakan dalam penelitian ini. Dalam pendekatan studi kasus yang digunakan ditekankan pada penggalian suatu permasalahan secara mendetail yang disertai dengan proses analisis yang melibatkan berbagai sumber informasi yang digunakan sebagai pendukung sumber data yang berkaitan dengan variabel penelitian (Creswell \& Creswell, 2017; Hanson et al., 2005). Dalam penelitian ini dikhususkan pada studi kasus pola asuh terutama terhadap anak disleksia (Kane et al., 2007).

Teknik wawancara, observasi dan dokumentasi berdasarkan studi kasus yang dilakukan digunakan dalam pengumpulan data pada penelitian ini (Baskarada, 2014; Tetnowski, 2015). Untuk tahapannya sendiri dimulai dari: (1) observasi, (2) wawancara, dan (3) dokumentasi. Untuk tahap observasi dilakukan untuk mengamati keadaan atau perilaku dari subjek 1 dan 2 baik saat proses belajar berlangsung maupun saat subjek berada di luar kelas. Observasi awal dilakukan di lembaga tersebut dan diperoleh informasi bahwa ada sekitar 6 orang anak dengan tingkat kemampuan membaca rendah yang diperoleh dari kelas 1-3 khususnya di tema-tema pelajaran yang membutuhkan kemampuan membaca. Kemudian penulis mengambil 2 diantaranya untuk dijadikan sampel berdasarkan tingkat kemampuan 
membaca (Nassaji, 2015; Sukmadinata, 2005). Subjek yang berjumlah dua orang ini diambil karena mengalami kesulitan yang lebih spesifik dan khas dibandingkan dengan subjek yang lain yaitu kesulitan membaca kompleks yang juga disebut dengan disleksia.

Tahapan berikutnya adalah wawancara. Untuk wawancara dilakukan secara terbuka untuk menggali data. Pengambilan data dilakukan dengan mewawancarai informan kunci, yaitu orang tua dan beberapa guru termasuk wali kelas yang secara langsung terlibat dengan anak baik di kediaman orangtua siswa maupun di Sekolah. Selanjutnya tahapan terakhir adalah dokumentasi. Untuk dokumentasi dilakukan dengan mempelajari catatan-catatan mengenai data pribadi baik dari anak maupun orangtua terkait pendidikan orangtua, keadaan social keluarga, pekerjaan orangtua, serta hasil belajar dari anak.

Selanjutnya keabsahan data menggunakan teknik triangulasi yaitu triangulasi sumber, yaitu dengan langkah: (1) membandingkan data hasil pengamatan dengan hasil wawancara, (2) membandingkan keadaan dengan berbagai pendapat seperti dosen misalnya, dan (3) membandingkan hasil wawancara dengan isi dokumen yang berkaitan. Prosedur yang dilakukan adalah dengan membandingkan antara hasil observasi, wawancara dan dokumentasi, jika hasilnya sesuai maka keabsahan datanya dapat dipertanggungjawabkan. Tetapi, jika hasilnya tidak sesuai maka digunakan hasil wawancara sebagai sumber data. Sumber wawancara meliputi: (1) Sumber A adalah kedua orangtua dari anak dengan kesulitan membaca atau disebut juga disleksia sebagai informan kunci; (2) Sumber B adalah guru perpustakaan yang terkadang mengajar menggantikan posisi wali kelas, dimana sumber B ini juga adalah orang yang paling memahami kondisi pada masing-masing subjek karena tinggal di wilayah yang sama dengan rumah yang berdekatan dengan lingkungan sekolah; (3) Sumber $\mathrm{C}$ adalah wali kelas yang mengetahui kondisi proses pembelajaran dari masingmasing subjek dan keadaan sosial anak ketika di dalam dan di luar kelas. Berikut skema gambar tahapan yang akan digunakan dalam penelitian ini :

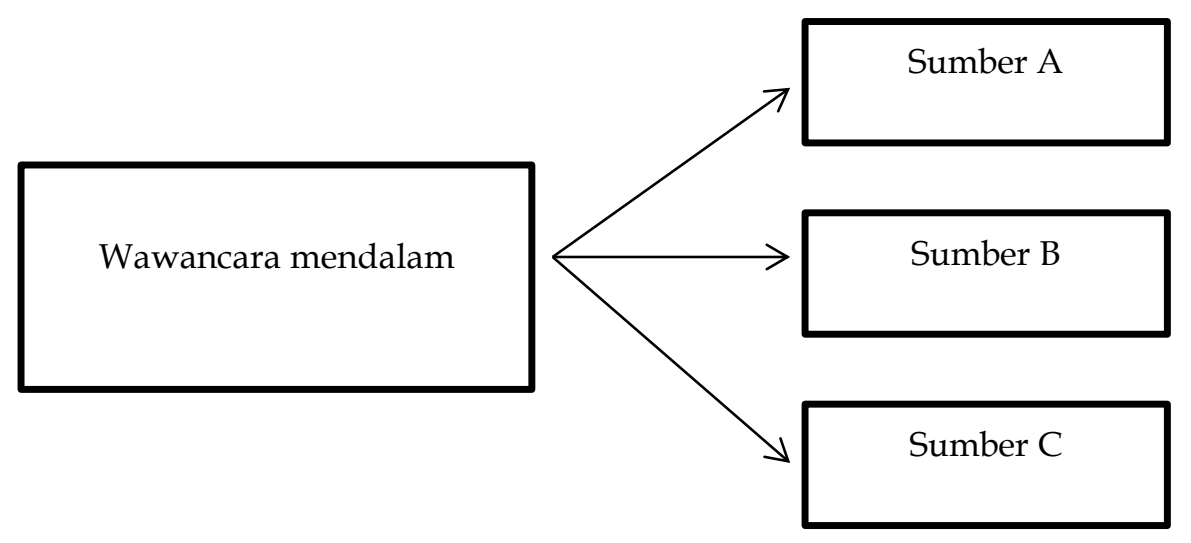

(Sugiyono, 2010)

\section{HASIL DAN PEMBAHASAN}

Penelitian ini mengkaji keterkaitan antara pola asuh orangtua terhadap kemampuan membaca anak disleksia. Tujuan penelitian ini adalah untuk menganalisis bentuk pola asuh orangtua yang sesuai dengan kondisi anak disleksia dalam upaya menangani kesulitan membaca. Berikut ini dijelaskan bentuk pola asuh yang diberikan orang tua terhadap anak mereka :

\section{Pola Asuh pada Subjek pertama}

Berdasarkan observasi yang penulis dapat deskripsikan, pola asuh yang diterapkan oleh nenek dari subjek 1 cukup otoriter. Pola asuh otoriter ini merupakan pola pengasuhan dengan orangtua atau dalam hal ini nenek memiliki tuntutan yang lebih besar dibandingkan dengan tanggapan yang harus diberikan. Ciri sederhana yang dapat terlihat dari pola 
pengasuhan ini adalah tidak adanya dorongan tingkah laku pada anak secara bebas sehingga membatasi anak (Baumrind, 1971). Hal ini, tidak mengherankan, terlebih untuk sang nenek yang telah berusia lanjut sehingga memiliki tuntutan tinggi terhadap subjek 1 . Keinginan sang nenek agar subjek 1 dapat menyamai teman-temannya dalam hal belajar justru membuatnya terlihat seperti memiliki beban ketika mengikuti pelajaran dengan materi dan penyampaian untuk anak-anak normal seusianya di kelas. Kurangnya perhatian dan penerimaan dari sang nenek membuat subjek 1 merasa kurang didengarkan sehingga ia lebih banyak diam di rumah tetapi menjadi sedikit tidak terkendali saat berada di sekolah.

Pengasuhan yang diperoleh dari sang nenek tersebut diakibatkan karena keadaan kedua orangtua dari subjek 1 yang disharmonis. Tidak adanya perhatian sejak kecil dari kedua orangtua secara langsung dan intens disebabkan karena kedua orangtuanya telah bercerai. Oleh karena keadaan tersebut, pengasuhan pun dilimpahkan kepada sang nenek yang sudah tua termasuk semua keperluan pendidikan dan biaya yang ditanggung dari usaha mengurus sawah orang lain. Keadaan seperti ini membuat sang nenek lebih banyak menghabiskan waktu untuk bekerja dibandingkan dengan memperhatikan pendidikan subjek 1 .

Berdasarkan hal tersebut di atas, maka untuk kasus subjek 1 pola asuh yang diterapkan termasuk ke dalam pola asuh otoriter atau authoritarian, ciri dari pengasuhan ini adalah (Baumrind, 1971; D. A. Brooks, 2017) : memberi nilai tinggi pada kepatuhan dan dipenuhinya permintaan, ini dibuktikan dengan keinginan dari sang nenek agar subjek 1 dapat menyamai teman-temannya dalam hal belajar; kemudian cenderung lebih suka menghukum, bersifat absolut dan disiplin, saat observasi maupun wawancara yang dilakukan tidak ada hukuman fisik yang didapatkan, namun terlihat saat subjek 1 berada di kelas dan merasa terbebani dengan keadaan. Ini membuktikan bahwa hukuman yang diberikan bukanlah hukuman fisik, namun mental; selain itu aturan dan standar tetap serta tidak adanya dorongan tingkah laku anak secara bebas sehingga cenderung membatasi anak.

\section{Pola Asuh pada Subjek Kedua}

Berbeda dengan subjek 2 yang masih memiliki orangtua lengkap dan utuh. Dalam memberikan pengasuhan, kedua orangtuanya mempertimbangkan usia, kemampuan, lingkungan, kondisi subjek 2 dan kondisi mereka sebagai orangtua sendiri. Menurut orangtua dari subjek 2, pola pengasuhan yang salah misalnya seperti kurangnya rasa kepercayaan terhadap anak, terlalu membatasi dan jarang memberikan motivasi moral maka anak tidak akan berkembang dan justru kehilangan kepercayaan diri. Orangtua pada subjek 2 adalah orang yang berpendidikan dan memiliki pekerjaan tetap, sehingga tidak heran jika mereka sangat memperhatikan pendidikan anaknya. Ibu dari subjek 2 tidak bekerja sehingga memiliki lebih banyak waktu untuk berinteraksi dengan anak, dan melakukan kontrol terhadap belajar anaknya ketika harus membuat kesepakatan waktu belajar.

Pola pengasuhan yang diberikan orangtua dari subjek 2 lebih mengedepankan interaksi dengan subjek 2. Seperti kebiasaan bercerita yang sering dilakukan, dimana sang anak diajak untuk bercerita kembali setelah mendengarkan cerita sebagai bentuk pola asuh demokratis. Selain itu, pembatasan dalam menonton televisi dengan memberikan jadwal kepada anak dan menggantikan waktu luang dengan mengenalkan bacaan-bacaan menarik sebagai bentuk pola asuh yang diterapkan. Ini membuktikan bahwa orangtua subjek 2 paham tentang bagaimana kondisi dari anak serta paham bagaimana seharusnya orangtua menempatkan diri.

Berdasarkan hal tersebut diatas, maka untuk kasus subjek 2 pola asuh yang diterapkan termasuk ke dalam pola asuh demokratis atau authoritative, ciri dari pengasuhan ini adalah (Baumrind, 1971; D. A. Brooks, 2017) : orientasi pada dialog dan diskusi keluarga; bersikap hangat namun tegas dengan mengatur standar sendiri agar dapat dilaksanakan dan memberi harapan yang konsisten terhadap kebutuhan dan kemampuan anak; memberi kesempatan anak untuk berkembang sendiri; menjelaskan disiplin yang mereka berikan kepada anak. 


\section{Perbandingan Pola Asuh}

Orangtua memiliki pola pengasuhan yang bebebeda-beda yang diterapkan kepada anakanak mereka. Hasil penelitian menunjukkan bahwa pola pengasuhan pada subjek 1 dan 2 dalam penelitian ini dapat dijabarkan dalam tabel 1 sebagai berikut :

Tabel 1: Tipologi Pengasuhan Subjek 1 dan 2

\begin{tabular}{|c|c|c|}
\hline \multirow{2}{*}{$\begin{array}{c}\text { Hal yang } \\
\text { diperhatikan }\end{array}$} & \multicolumn{2}{|c|}{ Klasifikasi Subjek } \\
\hline & Subjek 1 & Subjek 2 \\
\hline $\begin{array}{l}\text { Dominasi tuntutan } \\
\text { dan tanggapan }\end{array}$ & $\begin{array}{l}\text { Lebih banyak menuntut. } \\
\text { Memiliki tuntutan yang lebih } \\
\text { besar dibandingkan dengan } \\
\text { tanggapan yang harus } \\
\text { diberikan. }\end{array}$ & $\begin{array}{l}\text { Lebih banyak mendengar dan } \\
\text { memahami kondisi anak, sehingga } \\
\text { tanggapan lebih utama dibandingkan } \\
\text { tuntutan. }\end{array}$ \\
\hline Aturan & $\begin{array}{l}\text { Adanya aturan yang ketat } \\
\text { dari orangtua atau dalam hal } \\
\text { ini sang nenek }\end{array}$ & $\begin{array}{l}\text { Adanya pengendalian namun cenderung } \\
\text { memperhatikan keinginan dan pendapat } \\
\text { anak. }\end{array}$ \\
\hline Kontrol orangtua & $\begin{array}{l}\text { Kontrol kuat sehingga } \\
\text { membatasi anak. }\end{array}$ & $\begin{array}{l}\text { Adanya bimbingan dan kontrol dari } \\
\text { orangtua yang disesuaikan dengan } \\
\text { kondisi anak. }\end{array}$ \\
\hline $\begin{array}{l}\text { Kebebasan } \\
\text { berekspresi }\end{array}$ & $\begin{array}{l}\text { Cenderung tidak memberikan } \\
\text { kelonggaran }\end{array}$ & $\begin{array}{l}\text { Anak mendapatkan kesempatan untuk } \\
\text { mengemukakan pendapat } \\
\text { Anak diberikan kepercayaan }\end{array}$ \\
\hline $\begin{array}{l}\text { Reward \& } \\
\text { punishment }\end{array}$ & $\begin{array}{l}\text { Anak dihukum saat } \\
\text { melanggar aturan }\end{array}$ & \\
\hline
\end{tabular}

Berdasarkan proses pengamatan dan wawancara yang dilakukan terhadap kedua subjek dan informan kunci maka ditemukan keadaan Subjek 1 dalam kesehariannya tinggal dengan sang nenek, ini dikarenakan kedua orang tuanya telah bercerai. Di sekolah, subjek 1 menjadi siswa yang terlihat bermasalah karena nakal, susah dikendalikan dalam proses pembelajaran, sulit untuk mengikuti frekuensi pembelajaran temen-temannya yang lain, dan kesulitan dalam menuliskan nama lengkapnya. Ia memiliki kebingungan dalam membedakan huruf seperti $\mathrm{W}$ dan $\mathrm{M}$. Akibatnya ia sering diejek oleh teman-teman sekelasnya. Sedangkan untuk subjek 2 tinggal berbeda, ia tinggal dengan kedua orang tua lengkap dan utuh. Di sekolah subjek 2 cenderung pendiam dan jarang bersosialisasi. Namun, saat diajak berinteraksi lebih merespon saat ditanyai dan lebih mampu dikendalikan di dalam kelas. Subjek 2 kesulitan dalam merangkai huruf dan terkadang sering mengganti satu huruf dengan huruf yang berbeda. Saat diperintahkan untuk membaca, terkadang ada beberapa tanda baca dalam teks bacaan yang dilewatkan begitu saja.

Kemudian terkait dengan pendidikan, subjek 1 tidak mendapatkan pendidikan di tingkat sebelumnya, dalam artian ia sudah langsung disekolahkan di sekolah formal atau dalam hal ini Sekolah Dasar tanpa sebelumnya mengikuti pendidikan di PAUD. Hal ini juga sama dengan subjek 2 namun dengan alasan yang berbeda. Subjek 1 tidak langsung disekolahkan dengan alasan keterbatasan biaya dan latarbelakang kondisi sang nenek, sedangkan untuk Subjek 2 disebabkan karena orangtuanya adalah perantau dari daerah Kalimantan. Setelah proses berpindah tersebut, sebenarnya Subjek 2 telah beberapa kali coba dimasukkan di lembaga PAUD terdekat namun karena kondisi lingkungan baru, dengan alasan pribadinya tidak ingin melanjutkan sekolah lagi. Ini juga tentunya harus menjadi perhatian bersama terlebih untuk para orangtua, bahwa pendidikan informal atau pendidikan pra-sekolah sangat penting dalam membantu anak-anak menstimulasi awal perkembangan dan menemukan hambatan-hambatan dalam diri mereka. 
Selain itu, pola pengasuhan yang diberikan kepada subjek 1 dan 2 juga berbeda. Subjek 1 menerima pola pengasuhan otoriter dari nenek yang tinggal bersamanya. Seluruh keperluan biaya hidup dan pendidikan dibebankan pada sang nenek yang membuat semakin sedikitnya waktu untuk berkomunikasi dengan subjek 1 . Sebagian besar waktu sang nenek digunakan untuk bekerja. Untuk subjek 2 menerima pola pengasuhan dari orang tua lengkap dan utuh dengan pola pengasuhan demokratis. Dalam memberikan pengasuhan, kedua orangtuanya mempertimbangkan usia, kemampuan, lingkungan, kondisi subjek 2 dan kondisi mereka sebagai orangtua sendiri. Orangtua pada subjek 2 adalah orang yang berpendidikan dan memiliki pekerjaan tetap, sehingga tidak heran jika mereka sangat memperhatikan pendidikan anaknya. Ibu dari subjek 2 tidak bekerja sehingga memiliki lebih banyak waktu untuk berinteraksi dengan anak, dan melakukan kontrol terhadap belajar anaknya ketika harus membuat kesepakatan waktu belajar.

Untuk itulah, maka menjadi penting untuk memahami anak, orang tua, dan lingkungan. Disleksia dapat terjadi karena pola asuh yang diberikan oleh orangtua mengalami ketidaksesuaian baik dari kondisi atau keadaan anak maupun dari orangtua (Chatib Munif, 2012; Desiningrum, 2017). Dalam pengasuhan, para orang tua cenderung membesarkan anakanak mereka dalam pola asuh yang keliru maupun dalam lingkungan yang kurang mendukung. Akibatnya, pola asuh yang seperti ini menyebabkan terjadinya keterlambatan dalam perkembangan anak. Keterlambatan dalam bidang-bidang pertumbuhan dan perkembangan anak disebabkan oleh kurangnya perhatian, bimbingan dan pengetahuan orangtua terhadap perkembangan psikologi dan psikososial anak di jenjang usianya (Riati, 2016; Setiarani \& Suchyadi, 2018).

Pola asuh yang diterapkan oleh masing-masing orangtua terhadap anak sangat berpengaruh terhadap perkembangan anak terutama dalam belajar (Rimm, 2003). Ketika menerapkan pola asuh maka dibutuhkan cara-cara yang tepat dan mudah dipahami oleh anak. Berikut ini ada beberapa faktor yang mempengaruhi pola asuh (Belsky \& Barends, 2002; lestari, 2012; Prasetyawati, 2017) seperti: latar belakang pengasuhan orangtua, dalam hal ini orang tua mendapatkan pola pengasuhan dari yang pernah mereka dapatkan dari orang tua mereka sendiri; tingkat pendidikan orang tua yang berbeda, status ekonomi serta pekerjaan orangtua. Orang tua dengan status sosial ekonomi rendah biasanya mempunyai gaya pengasuhan otoriter, disiplin dan sering melakukan hukuman fisik. Namun, orang tua dengan status ekonomi tinggi umumnya menerapkan gaya pengasuhan authoritative (Gooding et al., 2011; lestari, 2012; Ningsih, 2015); keperibadian orangtua, yakni terkait dengan kestabilan emosi yang merupakan ciri kepribadian yang memengaruhi pengasuhan dan berkaitan dengan perilaku agresi dan masalah perhatian pada anak; karakteristik anak. Anak-anak yang menunjukkan perilaku "manis' maka orang tua akan dapat bersikap halus. Akan tetapi, bila anak berperilaku "tidak manis" maka akan menjadi penyebab orang tua bersikap kurang baik; konteks budaya sosial, contohnya seperti orangtua Amerika yang menerapkan pengasuhan individualistik untuk kompetensi dan kemandirian. Sedang orangtua Asia yang cenderung kolektivistik dengan orientasi kerjasama dan saling bergantung satu sama lain; status sosial ekonomi orangtua yang tinggi dan rendah berpengaruh terhadap pengasuhan yang diberikan kepada anak (García \& Gracia, 2014). Orangtua dengan tingkat sosio ekonomi rendah cenderung lebih mengendalikan, otoriter. Namun pada orangtua dengan tingkat sosio ekonomi tinggi cenderung lebih demokratis. Orangtua yang berpendapatan menengah dan tinggi lebih sering memikirkan pendidikan sebagai sesuatu yang harus didorong oleh orangtua dan guru. Sebaliknya, orangtua dengan pendapatan rendah lebih cenderung memandang pendidikan sebagai tugas guru (Akhyadi \& Mulyono, 2019; John W. Santrock, 2017).

Orangtua dapat menerapkan semua jenis pola asuh, baik itu pola asuh otoriter, pola asuh demokratis, maupun pola asuh permisif. Namun, kembali lagi, harus sebisa mungkin melihat kondisi atau keadaan dari masing-masing anak, karena tidak ada pola asuh yang salah satunya lebih baik dari yang lain termasuk dari ketiga jenis pola asuh tersebut. Semua pola 
asuh ini akan sangat membantu apabila orangtua mampu menempatkannya, terlebih untuk anak-anak dengan kondisi kesulitan belajar seperti disleksia.

Berikut ini ada beberapa ciri yang bisa dikenali oleh orangtua maupun guru untuk memahami sebenarnya bagaimana anak-anak disleksia. Disleksia itu diantaranya seperti disleksia dengan gangguan visual. Kelainan seperti ini disebabkan karena adanya gangguan fungsi otak bagian belakang yang dapat menimbulkan gangguan dalam persepsi visual (pengenalan visual tidak optimal, membuat kesalahan dalam membaca dan mengeja visual), dan rendah dalam memori visual. Kelainan ini terjadi sekitar $5 \%$ pada kasus disleksia (Lyon et al., 2003; Munawaroh \& Anggrayni, 2007). Contoh kesalahan terjadi seperti pada bentuk huruf-huruf atau angka yang hampir mirip bentuknya, yang merupakan bayangan dari huruf yang lain seperti huruf: b-d, p-q, 5-2, 3-E dan angka terbalik (inversion) seperti m-w, n-u, 6-9. Hal ini terlihat nyata pada tulisannya.

Kemudian disleksia dengan gangguan bahasa. Kelainan ini dikenal juga sebagai kelainan verbal atau linguistik. Pada kelainan ini anak-anak mengalami keterlambatan berbicara yang terjadi pada masa balita atau prasekolah. Data menyebutkan kelainan ini didapatkan pada sekitar $4 \%$ dari semua anak laki-laki dan $1 \%$ pada anak perempuan (Endang Widyorini, 2017). Gejalanya berupa kesulitan dalam persepsi auditoris seperti $\mathrm{p}-\mathrm{t}, \mathrm{b}-\mathrm{g}, \mathrm{t}-\mathrm{d}$, tk; kesulitan mengeja secara auditoris, kesulitan menyebut atau menemukan kata atau kalimat, urutan auditoris yang kacau (sekolah $\rightarrow$ sekolha). Hal ini berdampak pada imla atau dalam membuat karangan(Andamari \& Amalia, 2017).

Selain itu, ada disleksia dengan gangguan visual-Auditoris. Pada disleksia ini terdapat ganguan pada kondisi visual-auditoris (grafem-fonem), anak membaca lambat. Dalam hal ini bahasa verbal dan persepsi visualnya baik apa yang dilihat tidak dapat dinyatakan dalam bunyi bahasa(Litt \& Nation, 2014). Ini terlihat pada anak-anak memiliki kemampuan membaca dengan cepat namun terlihat membuat kesalahan-kesalahan seperti penghliangan, penambahan, dan atau penggantian huruf serta kesalahan-kesalahan lainnya. Selain itu, terlihat pada anak yang membaca lambat dan juga kesalahan-kesalahan seperti membaca putus-putus dan sering mengulang-ulang.

Para orang tua harus memahami bahwa disleksia bukanlah sebuah penyakit, namun sebuah gangguan pembelajaran yang merujuk ke anak yang mengalami masalah dalam membaca dan menulis walaupun anak-anak tersebut memiliki pemikiran yang normal. Untuk itu memamahami perkembangan anak sejak dini sangat penting untuk dilakukan (Habibi, 2015). Jika lingkungan baik dan positif, maka anak akan dapat menanamkan dan mengembangkan sendiri keinginannya dalam belajar. Maka, semakin baik pola asuh orangtua dan penerimaan positif dari lingkungan (lingkungan mendukung pola asuh), maka akan mengurangi serta mencegah terjadinya disleksia pada anak, terutama di usia-usia awal memasuki sekolah formal. Beberapa penelitian telah menunjukkan adanya korelasi positif antara pola asuh yang diberikan terhadap perkembangan kemampuan anak yang mengalami disleksia (Amin, 2018; Delany, 2017; Huang et al., 2020)

Lingkungan keluarga memegang peranan penting dalam proses belajar, sebab lingkungan keluarga adalah pendidikan pertama untuk anak, khususnya dalam melatih pengenalan bunyi (fonem) dan pengenalan huruf (G. Brooks, 2013; Madyawati, 2016). Hal ini juga menjelaskan bahwa pengasuhan itu merupakan sebuah proses interaksi antara orangtua dengan anak yang berkelanjutan dan proses tersebut memberikan perubahan baik pada keduanya (Akhyadi \& Mulyono, 2019). Dampak positif dari pengasuhan baik yang dilakukan oleh orangtua adalah sebagai jalan menuju perkembangan dan hasil kehidupan yang baik. Sehingga menjadi target dalam intervensi awal, pencegahan, dan pengobatan (Sanders \& Turner, 2018).

Untuk dampak ke depannya, anak-anak dengan kondisi seperti ini akan sulit untuk mengikuti tahapan perkembangan selanjutnya, khususnya pada kemampuan membaca permulaan, dimana pada tahapan ini anak akan dituntut untuk mampu membaca secara teknis seperti menguasai kode alfabetik sebelum mampu memahami apa yang disampaikan 
penulis (Petty \& Jensen, 1980). Jika hal tersebut belum mampu dikuasai, maka prestasi belajarnya akan rendah dan tujuan pendidikan tidak tercapai dengan maksimal (Widodo et al., 2020). Pendeteksian awal menjadi sangat penting dalam hal ini terutama untuk anak-anak dalam masa transisi belajar seperti PAUD ke SD sehingga stimulus dan dukungan dapat diberikan sedini mungkin. Untuk itu, pola asuh yang sesuai yang diberikan orang tua menjadi sangat penting dalam proses perkembangan anak, khususnya untuk anak disleksia dalam penelitian ini.

\section{SIMPULAN}

Pola asuh yang diterapkan oleh orangtua secara tidak langsung dapat mempengaruhi kehidupan masa depan seorang anak, seperti studi kasus tentang kesulitan belajar disleksia. Ini adalah bentuk dari pencegahan dini yang dapat dilakukan oleh orangtua dengan kondisi anak yang sama. Untuk itu pola asuh demokratis atau authoritative dengan adanya keterbukaan dan komunikasi antara orang tua dan anak dapat dijadikan sebagai salah satu rekomendasi pola asuh bagi anak disleksia. Orangtua dapat menerapkannya kepada anak dengan melihat kondisi serta batasan-batasan tertentu pada masing-masing anak.

\section{UCAPAN TERIMA KASIH}

Terimakasih sebesar-besarnya penulis ucapkan kepada semua pihak yang telah terlibat dalam memberikan masukan dan kesediaan dalam terlaksananya penelitian ini, diantaranya Kepala Sekolah, para guru, orangtua, dosen pembimbing lapangan dan pihak-pihak lainnya.

\section{DAFTAR PUSTAKA}

Adawiah, R. (2017). Pola Asuh Orang Tua Dan Implikasinya Terhadap Pendidikan Anak: Studi Pada Masyarakat Dayak Di Kecamatan Halong Kabupaten Balangan. Jurnal Pendidikan Kewarganegaraan, 7(1), 33-48.

Ahuja, A., \& Khan, W. (2015). Social support and well-being of mothers of dyslexic children. Indian Journal of Health and Wellbeing, 6(2), 133-137. https:// search.proquest.com/docview/1679425865?accountid=14700\%5Cnhttp:/ / otago. hosted.exlibrisgroup.com/openurl/DUNEDIN/DUNEDIN_SERVICES_PAGE??url_ver= Z39.88-

2004\&rft_val_fmt=info:ofi/fmt:kev:mtx:journal\&genre=article\&sid=ProQ:ProQ\%3Ahealt hcompleteshell\&atit

Akhyadi, A. S., \& Mulyono, D. (2019). Program Parenting dalam Meningkatkan Kualitas Pendidikan Keluarga. Abdimas Siliwangi, 1(1), 1-8. https://doi.org/10.22460/as.v1i1p18.34

Al Tridhonanto. (2014). Mengembangkan Pola Asuh Demokratis - Al.Tridonanto - Google Books. Elex Media Komputindo; Elex Media Komputindo. https:/ / books.google.co.id/books?id=JuBMDwAAQBAJ\&pg=PA12\&dq=pola+asuh\&hl= en\&sa $=$ X\&ved=2ahUKEwip8-

f4k4nsAhVUVH0KHVChC6kQ6AEwAHoECAEQAQ\#v=onepage \&q=pola asuh\&f=false

Amin, B. (2018). Parental Acceptance terhadap Anak dengan Disleksia dalam Film Wonderful Life. INKLUSI, 5(1), 133. https:/ / doi.org/10.14421/ijds.050107

Andamari, S. R., \& Amalia, U. (2017). Implementasi Terapi Disleksia Berbasis Android dan Terapi Disleksia Verbal Terhadap Peningkatan Kemampuan Membaca Pada Anak Disleksia. Psikologia : Jurnal Psikologi, 2(1), 17. https://doi.org/10.21070/psikologia.v2i1.1073

Band-Winterstein, T., \& Avieli, H. (2017). The Experience of Parenting a Child With Disability in Old Age. Journal of Nursing Scholarship, 49(4), 421-428. https://doi.org/10.1111/jnu.12305

Baškarada, S. (2014). Qualitative Case Study Guidelines. The Qualitative Report, 19(40), 1-18. http://nsuworks.nova.edu/tqr/vol19/iss40/3

Baumrind, D. (1971). Current patterns of parental authority. Developmental Psychology, 4(1 PART 2), 1-103. https:// doi.org/10.1037/h0030372

Belsky, J., \& Barends, N. (2002). Personality and parenting. 
Biro Pusat Statistik (BPS). (1987). Statistik Indonesia Tahun 1986. In Jakarta Pusat: Badan Pusat Statistik. https://www.bps.go.id/

Brooks, D. A. (2017). Printing and parenting in early modern england. In Printing and Parenting in Early Modern England. Routledge. https://doi.org/10.4324/9781315246031

Brooks, G. (2013). What works for children and young people with literacy difficulties? The effectiveness of intervention schemes. 4th edition. In The effectiveness of intervention schemes.

Chatib Munif. (2012). Orangtuanya Manusia: Melejitkan potensi dan kecerdasan dengan menghargai fitrah setiap anak. Kaifa.

Creswell, J. W., \& Creswell, J. D. (2017). Research design: Qualitative, quantitative, and mixed methods approaches. Sage publications.

Desiningrum, D. R. (2017). Psikologi anak berkebutuhan khusus. psikosain.

Devina, G., \& Penny, H. (2016). Gambaran Proses Penerimaan Diri Ibu Yang Memiliki Anak Disleksia. Journal of Disability Studies, 3(1), 44-52.

Endang Widyorini. (2017). DISLEKSIA Deteksi Diagnosis Penanganan di Sekolah dan di Rumah. Kencana.

García, F., \& Gracia, E. (2014). The Indulgent Parenting Style and Developmental Outcomes in South European and Latin American Countries. In Parenting across cultures (pp. 419-433). Springer. https://doi.org/10.1007/978-94-007-7503-9_31

Gooding, J. S., Cooper, L. G., Blaine, A. I., Franck, L. S., Howse, J. L., \& Berns, S. D. (2011). Family Support and Family-Centered Care in the Neonatal Intensive Care Unit: Origins, Advances, Impact. In Seminars in Perinatology (Vol. 35, Issue 1, pp. 20-28). Elsevier. https:// doi.org/10.1053/j.semperi.2010.10.004

Grigorenko, E. L. (n.d.). Report on the Russian language for the World Dyslexia Forum 2010. World Dyslexia Forum at UNESCO, Paris.

Habibi, M. (2015). Analisis Kebutuhan Anak Usia Dini. Deepublish.

Hanson, W. E., Plano Clark, V. L., Petska, K. S., Creswell, J. W., \& Creswell, J. D. (2005). Mixed methods research designs in counseling psychology. In Journal of Counseling Psychology (Vol. 52, Issue 2, pp. 224-235). American Psychological Association. https://doi.org/10.1037/0022-0167.52.2.224

Huang, Y., He, M., Li, A., Lin, Y., Zhang, X., \& Wu, K. (2020). Personality, behavior characteristics, and life quality impact of children with dyslexia. International Journal of Environmental Research and Public Health, 17(4), 1415. https:// doi.org/10.3390/ijerph17041415

Hyett, N., Kenny, A., \& Dickson-Swift, V. (2014). Methodology or method a critical review of qualitative case study reports. In International Journal of Qualitative Studies on Health and Well-being (Vol. 9, Issue 1, p. 23606). Taylor \& Francis. https://doi.org/10.3402/qhw.v9.23606

JAMARIS EDWITA, M. (2014). Formal Multiple Intelligences Assessment Instruments for 4-6 Years Old Children. American Journal of Educational Research, 2(12), 1164-1174. https://doi.org/10.12691/education-2-12-6

John W. Santrock. (2017). LIFE-SPAN Development (13th ed.). In McGraw-Hill (Vol. 91, Issue 2).

Kane, G. A., Wood, V. A., \& Barlow, J. (2007). Parenting programmes: A systematic review and synthesis of qualitative research. In Child: Care, Health and Development (Vol. 33, Issue 6, pp. 784-793). Wiley Online Library. https:// doi.org/10.1111/j.1365-2214.2007.00750.x

lestari, S. (2012). Psikologi Keluarga: Penanaman Nilai dan Penanganan Konflik dalam Keluarga,. Jakarta:Prenada Media Group, 50.

Litt, R. A., \& Nation, K. (2014). The nature and specificity of paired associate learning deficits in children with dyslexia. Journal of Memory and Language, 71(1), 71-88. https://doi.org/10.1016/j.jml.2013.10.005

Lyon, G. R., Shaywitz, S. E., \& Shaywitz, B. A. (2003). A Definition of Dyslexia. In Annals of Dyslexia (Vol. 53, Issue 1, pp. 1-14). Springer. https:// doi.org/10.1007/s11881-003-0001-9

Madyawati, L. (2016). Strategi Pengembangan bahasa pada Anak. Kencana.

Mhd. Hamzah Fansuri Hsb. (2019). Permasalahan Pada Otak (DISLEKSIA) Berpengaruh Pada Kemampuan Berbahasa. Jurnal Pendidikan Bahasa Dan Sastra Indonesia, 3(2), 78-84.

Munawaroh, M., \& Anggrayni, N. T. (2007). Mengenali Tanda-Tanda Disleksia Pada Anak Usia Dini. Pgsd, 167-171. 
DOI: 10.31004 /obsesi.v5i2.645

Nassaji, H. (2015). Qualitative and descriptive research: Data type versus data analysis. In Language Teaching Research (Vol. 19, Issue 2, pp. 129-132). Sage Publications Sage UK: London, England. https://doi.org/10.1177/1362168815572747

Ni'mah, K. (2018). Pola Komunikasi Keluarga dan Pengasuhan Ramah Anak Sebagai Upaya Membentuk Kepribadian Anak. KOMUNIKA: Jurnal Dakwah Dan Komunikasi, 12(1). https://doi.org/10.24090/komunika.v12i1.1326

Ningsih, W. (2015). Perbedaan gaya pengasuhan pada ayah yang bekerja dan ibu yang bekerja (pp. 11-28). Universitas Islam Negeri Sultan Syarif Kasim Riau.

Nooraeni, R. (2017). Implementasi Program Parenting Dalam Menumbuhkan Perilaku Pengasuhan Positif Orang Tua Di PAUD Tulip Tarogong Kaler Garut. Jurnal Pendidikan Luar Sekolah, 13(2).

Petty, W. T., \& Jensen, J. M. (1980). Developing children's language. Allyn and Bacon.

Prasetyawati, A. E. (2017). Kedokteran Keluarga. Rineka Cipta, Jakarta, 2(2), 67-72.

Pratamawati, T., Solikhah, A., \& Haryani, S. (2015). Perspektif Negatif terhadap Anak Disleksia tanpa Mempedulikan Potensi yang Dimiliki. Proseding Seminar Nasional PGSD UPY Dengan Tema Strategi Mengatasi Kesulitan Belajar Ketika Murid Anda Seorang Disleksia, 154-161.

Reid, G. (2016). Dyslexia: A practitioner's handbook. John Wiley \& Sons.

Riati, I. K. (2016). Pengaruh Pola Asuh Orang Tua Terhadap Karakter Anak Usia Dini. Jurnal Infantia, 4(2).

Rimm, S. D. (2003). Mendidik dan Menerapkan Dispilin pada Anak Prasekolah. Gramedia Pustaka Utama.

Sanders, M. R., \& Turner, K. M. T. (2018). The importance of parenting in influencing the lives of children. In Handbook of Parenting and Child Development Across the Lifespan (pp. 3-26). Springer. https://doi.org/10.1007/978-3-319-94598-9_1

Setiarani, S., \& Suchyadi, Y. (2018). Pola Asuh Orang Tua Terhadap Anak Tuna Netra Berprestasi Usia Sekolah Dasar. Jurnal Pendidikan Dan Pengajaran Guru Sekolah Dasar (JPPGuseda), 1(1), 15-18. https://doi.org/10.33751/jppguseda.v1i01.866

Shaywitz, S. E., \& Shaywitz, B. A. (2007). The neurobiology of reading and dyslexia. In ASHA Leader (Vol. 12, Issue 12, pp. 20-21). Elsevier. https:/ / doi.org/10.1044/leader.ftr7.12122007.20

Sugiyono, S. (2010). Metode penelitian kuantitatif dan kualitatif dan RED. ALFABETA Bandung.

Sukmadinata, S. N. (2005). Metode Penelitia. Bandung: PT Remaja Rosdakarya.

Suryani, Y. E. (2010). Kesulitan belajar. Magistra, 22(73), 33-47.

Tamasse, M. (2017). Mengatasi kesulitan belajar disleksia (studi neuropsikolinguistik).

Tetnowski, J. (2015). Qualitative Case Study Research Design. Perspectives on Fluency and Fluency Disorders, 25(1), 39-45. https:// doi.org/10.1044/ffd25.1.39

Vellutino, F. R., Fletcher, J. M., Snowling, M. J., \& Scanlon, D. M. (2004). Specific reading disability (dyslexia): What have we learned in the past four decades? In Journal of Child Psychology and Psychiatry and Allied Disciplines (Vol. 45, Issue 1, pp. 2-40). Wiley Online Library. https://doi.org/10.1046/j.0021-9630.2003.00305.x

Widodo, A., Indraswati, D., \& Royana, A. (2020). Analisis Penggunaan Media Gambar Berseri Untuk Meningkatkan Kemampuan Membaca Siswa Disleksia Di Sekolsh Dasar. MAGISTRA: Media Pengembangan Ilmu Pendidikan Dasar Dan Keislaman, 11(1), 1. https:/ / doi.org/10.31942/mgs.v11i1.3457

Wiguna, T. (2016). The Importance of Parent - Infant Bonding towards Infant Mood Regulation. Sari Pediatri, 17(6), 478. https:// doi.org/10.14238/sp17.6.2016.478-84 